Zhengis. Zh.

Shamanizm or Tengrian?

Жеңіс ж.ж.

Тәңіршілдік пе әлде шаманизм бе?

Женис Ж.Ж.

Тенгрианства ими шаманизм?
In modern scientific environment traditional world out-look of turks is called "shamanizm", under the name of the religious representative. This obvious distortion of the name, as well as earlier, the Europeans named islam as "magoumetin" or "busurmanian". Actually, shamanizm to the attitude to shaman not religion, and only activity of the separate persons, which has the special quality. Owning in the special quality shaman was engaged by treatment, prediction or indication of miracles. Thus shamans have realized, what is it qualities given most Tengri by means of spirit of ancestors.

Key words: shamanizm, tengrian, medieval turks, turkish state and others.

ТүркілерАің Аәстүрлі Аіни сенімі ТәңіршілАіктің қазіргі ғылыми ортада осы сенімнің Аіни өкілінің атауына байланысты «шаманизм» деп аталатыны белгілі. Бұл кезінде еуропалықтардың ислам Аінін «магометанство» немесе «басурманство» деп төмендете атағаны сияқты көпе-көрнеу бұрмалау болды. Тәңірі сенімінің Аіни өкілі шаманға немесе бақсыға қатысты шамандық дін емес - бар болғаны айрықша қасиеті бар жеке тұлғаның жеке іс-әрекеті еді. Өзіне Тәңірі тарапынан бақсылық немесе шамандық қасиет қонған кісі емшілікпен, көріпкелдікпен, адам санасынан тыс кереметтер көрсетумен айналысты.

Түйін сөздер: көне түркілер, Аәстүрлі дүниетаным, тәңіршілдік және басқалар.

В современной научной среде традиционное мировоззрение тюрков - тенгрианство по названию религиозного преАставителя этой веры называется «шаманизм». Это явное искажение названия, как и ранее, и европейцы исламом называли «магометанство» и^и «басурманство». На самом деле, шаманизм к отношению к шаману не религия, а всего ^ишь Аеятельность отАельного лица, который имеет особое качество. ВлаАеющий особым качеством шаман занимался мечением, преАсказанием или показанием чудес.

Ключевые слова: Аревние тюрки, традиционное мировоззрение, тенгрианство и Ар. 


\section{SHAMANIZM OR TENGRIAN?}

In modern scientific environment traditional world out-look of turks is called "shamanizm", under the name of the religious representative. This obvious distortion of the name, as well as earlier, the Europeans named islam as "magoumetin" or "busurmanian". Actually, shamanizm to the attitude to shaman not religion, and only activity of the separate persons, which has the special quality. Owning in the special quality shaman was engaged by treatment, prediction or indication of miracles. Thus shamans have realized, what is it qualities given most Tengri by means of spirit of ancestors. Therefore shamans never resisted to will Tengri. The Kazakh philosopher G.Esim analyzing the data on this theme will make a conclusion that "shamanizm not religion, and activity of the private person" $[1,17]$. The turkish scientist A.Donuk, investigating this theme has made a conclusion: "a Source of spiritual force turks became tengrian. Thus among turks there was no image Tengri, idol or temple. Turks associated all with Tengri. Therefore, it is impossible to consider religion turkov "shamanizm" $[2,112]$. Even, the hakasian scientist V.Butanaev informs: "up to a beginning XX c. the researchers have not noticed among hakass and altais others religious except for shamanizm. The travellers, officials, even the believers Hongorai of the local peoples considered idolists-shamans. ... The researcher D.Lappo has noticed monoteism among hakass. He in the book «Troeverie», which was issued in 1905 has noticed, «they (hakass) believed Unique of Tengri «. Hakases never confused faith to Tengri to activity shaman $[3,10]$. On this to name traditional world out-look of turks «shamanizm» it is incorrect. L.Gumilev about it has noticed: «if to say about ancient faith of turks, I can not name it primitive religious. State of turks concerns to V-VI c.c., therefore faith of turks began to develop, as all religions of this time».

Certainly, as the religious person, shamans had social meaning. But, in anciently society of state system, which was based on traditional world out-look, shamans the access to authority was limited, though they had the important place. Despite of the special religious rule shamans they basically were engaged only in prediction and treatment. With the help shamans- "iadatci", which had a sacred stone of "poison", influenced weather and have managed to cause a rain, storm, snow.

In anciently turks monuments and in the documents the side between tengrianm and shamanizm is precisely determined. 
For example in «Shahname» in time the iranianturanian relation an important role played shamans:

\section{Ze Turkon ieki bud Bozur nom \\ Bofsun behar djoe gostarde kam \\ Biomuhte kaji va djovi [5,359]}

Translation: Among turkov was Bozur

$\mathrm{He}$ is skilful to conjure.

It(him) the witchcraft force passed everywhere.

Komander by armies Turan Piran send him to iranian:

Ke az on gift borou that sare tih e kuh

Barf va sarmo va bod damon.

Baroeshon a biobar ham ondar zamon. [5,359]

Translation: Go from here to top of a mountain,

And therefrom send to them snow, cold and wind.

In one place of this epos:

Va az in ru a bar omad ieki tond bod

Ke kasi ro az Iron nabod razm iod.

Ieki abre tond andar omad chu gard

Ze sarmo hami lab bedandon fesard.

Saro parde va hamiho gasht iah

Keshid az a bar kuh a bar barfe yah. [5,331]

\section{Translation:}

The wind is visible on the one hand,

Behind it(him) there was a cloud.

From colds of a lip frozen to teeth,

The tents have frozen.

The snow has fallen on top of a mountain.

In general, in medieval turks society shamans in some cases the authorities have achieved. For example, the king which has managed to concentrate religious - political authority and witchcraft was in the state at «shu». Then «hakan» (kagan) has received spiritual authority, his assistant «ugrush» has received secular authority. The given system existed at argippais, then at turks $[6,18]$. Sometimes shamans received access to state authority. For example, in the epic chronicle «Tanshu» such interesting fact is given: «... In him among 70 brothers Nishandu had wonderful qualities. Has managed to send a wind and rain. He had two wives. One of them was the daughter of a ruller of summer(years), another - was the daughter of the owner of winter. Then descendants of Nishandu steel founders of the state Tuku. But, with development turks states shamans have limited from authority. The reason it became first, the quantity of the applicants on a throne among shamans was not numerous, secondly, turkish to know were afraid from arrival of the unusual applicants on authority.

And so, in a stage of development Turkish state shamans were limited on religious businesses. Till now in tradition saha shamans which brought sacrifice, can not participate on a holiday «Yurungari touon and isiah». Hakass shamans, nor can be asked on «Quday» [7,98]. In ancient Turkish states shamans also are imperceptible as the state figures.

About a role of shamans in ancient Turkish a society M. Kashkari defines a word «toyon». «Toyon - name of the representatives, not adopted islam. He is equal imams and mufties. Toyon costs at a temple and reads the books. Let will be damned» [8]. Besides, ancient turks shamans named «kam», in «Kutadgu Bilik» Balasaguni «kam» named medics $[9,409]$.

As we see, in a medieval turkish society (community) shamans had two functions. First, they were engaged witchcraft, treatment, prediction. Therefore they had respect and fear before the population. Secondly, though they were one of the persons, close to the governor, in the state, but were and at the same time one of the basic contenders nobles. By the main obstacle on reception of complete authority in the state prevented only Tengri, which was the basic nucleus faith of turks. Therefore, not shaman, and fair and powerful Tengri has remained the main object of bow at turks.

With acceptance turks islam, the synthesis traditional religious of turks with islam has borrowed long process. In the beginning islam, which has the perfect and new system, could not quickly absorb to itself worn-out, old faith of turks. Even, sometimes this process caused the contradiction. Especially, at persecution free islam and celebration dogmatic islam the interrelation between islam and tengrian developed very much is intense. In a islamic society which triumphed dogmatism the rests and relicts ancient faith among «modern turks» was considered of vestiges of barbarity and backwardness. For example Biruni, the famous scientist of the time writes: «one turk to me has brought a stone «of a poison», and he thought me to please. I to him have said: «if you can with the help of this stone to cause a rain I of the ladies to you that want». He has put a stone on water and muttered something and beginnings to shout. But from it nothing has left. On this trifle be believe even turkish to know. When I have told about it to one turk he has said to me that the stone of «poison» is valid only on ground of turks» $[11,205]$.

As saw relicts of ancient turks it was not simple to go through but new society, which triumphed new 
religious values. All as tengrian has managed to save of the religious elements among layers of islam.

The ambassador acceptance islam the population of Central Asia tengrian had the islamic forms. As has said V.N. Basilov "now contradiction between mullah and shaman was not collision of dif- ferent ideology, and only professional competition. In world out-look of shamans did not differ from others devout. Shamans before that to not act theiers religious rituals turned ones attention first to Allah and different islamic sacred, then to spirits - assistants and angels" $[12,206]$.

\section{Әдебиеттер}

1 Есім Г. Шаманизм деген не?. - Алматы: Ақиқат. 1996. - №2. - 11-25 бб.

2 Donuk A, Gok turk kitabelerinin dini acidan degerlendirilmesi // Gok turk devletinin 1450.kurulus yildonumu. Sempozyum bildirileri. - Ankara: 2001. 142 c.

3 Бутанаев В.И. Бурханизм тюрков Саяно-Алтая. - Абакан, 2003. - 260 с.

4 Гумилев Л.Н. Көне түркілер. - Алматы: Білім, 1994. - 381 б.

5 Фердауси А. Шахнаме. Толық текст. - Техран: Катре баспасы, 1374, - 1368 б.

6 Бекжан О. Тоныкөк. Түркі тұлғалары. - Түркістан, Тұран. 2006. - 600 б.

7 Алексеев Н.А. Шаманизм тюркоязычных народов Сибири. - Новосибирск: Наука, 1984. - 233 с.

8 Кашкари М. Түрік сөздігі: - Алматы, Хант, 1998. - 600 б.

9 Радлов В.В. Из Сибири. - М.: Восточная литература, 1989. - 749 с.

10 Бұлытай М. Ата-баба діні? Түркілер қалай мұсылман болды? - Алматы: Білім. 2001 - 504 б.

11 Бируни А. Избранное произведения. 1Т. - Ташкент, 1957. - 487 с.

12 Басилов В.Н. Избранники духов. - М.: Политиздат, 1984. - 207 с.

\section{References}

1 Esim G. Shamanizm degen ne?. - Almaty: Ақіқаt. 1996. - №2. - 11-25 bb.

2 Donuk A, Gok turk kitabelerinin dini acidan degerlendirilmesi // Gok turk devletinin 1450.kurulus yildonumu. Sempozyum bildirileri. - Ankara: 2001. - $142 \mathrm{c}$.

3 Butanaev V.I. Burhanizm tjurkov Sajano-Altaja. - Abakan, 2003. - 260 s.

4 Gumilev L.N. Kene tyrkiler. - Almaty: Bilim, 1994. - 381 b.

5 Ferdausi A. Shahname. Tolyқ tekst. - Tehran: Katre baspasy, 1374, - 1368 b.

6 Bekzhan O. Tonykek. TYrki tұlfalary. - TYrkistan, Tұran. 2006. - 600 b.

7 Alekseev N.A. Shamanizm tjurkojazychnyh narodov Sibiri. - Novosibirsk: Nauka, 1984. -233 s.

8 Kashkari M. Tyrik sezdigi: - Almaty, Hant, 1998. - 600 b.

9 Radlov V.V. Iz Sibiri. - M.: Vostochnaja literatura, 1989. - $749 \mathrm{~s}$.

10 Błlytaj M. Ata-baba dini? Tyrkiler қalaj mұsylman boldy? - Almaty: Bilim. 2001 - 504 b.

11 Biruni A. Izbrannoe proizvedenija. 1T. - Tashkent, 1957. - $487 \mathrm{c}$.

12 Basilov V.N. Izbranniki duhov. - M.: Politizdat, 1984. - 207 s. 